\title{
Olhando o futuro
}

\section{Looking at the future}

\section{José Vasconcelos-Raposo}

EDITORIAL | EDITORIAL

Em Junho passado, recebemos a gratificante notícia da integração da Revista Motricidade na ISI Web of Knowledge. Este feito resultou do esforço de todos aqueles que de uma forma direta ou indireta apostaram na Motricidade, quer fosse aceitando-a como a plataforma para divulgar os seus trabalhos científicos, quer fosse no empenho e dedicação, por vezes com sacrifício pessoal, para que atempadamente a Motricidade fosse editada.

Desde que assumimos a direção da revista em momento algum nos atrasamos no lançamento dos números e quando esse atraso se verificou (o que aconteceu uma vez) não foi por nossa responsabilidade.

Por enquanto, mantemos um duplo formato: papel e digital. Ao longo de 2014 esperamos estar apenas em formato digital. Esta opção visa reforçar o nosso compromisso com as políticas de acesso aberto. $\mathrm{Na}$ essência o que desejamos é que os trabalhos publicados na Motricidade sejam o mais expostos possíveis, daí que são bem vindas todas as iniciativas de baixarem do nosso sítio da internet os artigos e que os coloquem em outras bases de dados sejam pessoais ou de qualquer outra natureza.

Para nossa surpresa, temos assistido a um acréscimo de pedidos de subscrição da revista em formato de papel. De alguma forma, temos desencorajado as assinaturas e procuramos redefinir a nossa relação com aquelas bases de indexação com que, inicialmente, nos havíamos comprometido oferecer a revista em formato de papel.

Ao longo dos anos temos assistido a uma crescente procura e consulta da nossa base de dados. É no período de Março, Abril e Maio que atingimos os picos de procura, altura em que no ano de 2013 assistimos a uma média de aproximadamente 20300 visualizações sendo que um pouco mais de $70 \%$ eram novos visitantes. Também assistimos ao aumento no número de procuras vindas de países cuja língua não é o português que visitam a revista, mas permanecem pouco tempo nas nossas páginas e baixam um reduzido número de manuscritos. Tal facto sugere que agora, porventura, é tempo de procurar encontrar os mecanismos necessários para que a revista possa ser oferecida num formato bilingue. Nos próximos tempos iremos estudar esta possibilidade.

O número de artigos submetidos tem aumentado e com esse aumento repercutiu-se, também, na qualidade dos trabalhos. Face a esta constatação, e porque o número de artigos cujo mérito justifica a sua publicação aumentou significativamente, não tivemos outra opção se não a de aumentar o número de artigos a serem publicados por número. Assim, com a presente edição aumentamos em de cerca de $50 \%$ os artigos a publicar por número. Procuraremos, no futuro, implementar políticas que tenham por objectivo dar um escoamento o mais rápido possível aos manuscritos submetidos e aceites para publicação.

A área das ciências da saúde/médica têm ganho expressão na Motricidade, mas é nosso desejo manter a matriz das nossas raízes, assim iremos implementar medidas no sentido de aumentar a publicação de artigos também na área da psicologia. Porém a nossa vocação inicial mantém-se intata e por essa 
2 | J. Vasconcelos-Raposo

razão, agora que passamos a ISI esperamos ver crescer as submissões nas áreas científicas do desporto.

A todos que connosco colaboram um sincero obrigado pelo apoio dado e sem o qual não teríamos o sucesso até agora obtido. Juntos podemos crescer ainda mais.

$((c)$ EY-No Todo o conteúdo da revista Motricidade está licenciado sob a Creative Commons, exceto quando especificado em contrário e nos conteúdos retirados de outras fontes bibliográficas. 